\title{
Predictors of Bacterial Meningitis among Paediatric Patients Aged 0 - 5 Years at Kenyatta Hospital, Kenya
}

\author{
June J. Serem*, Margaret Chege, Dorcas Maina \\ College of Health Sciences, School of Nursing Sciences, University of Nairobi, Nairobi, Kenya \\ Email: junserem@gmail.com, Margaret.chege@gmail.com, dwaithira94@gmail.com
}

How to cite this paper: Serem, J.J., Chege, M. and Maina, D. (2018) Predictors of Bacterial Meningitis among Paediatric Patients Aged 0 - 5 Years at Kenyatta Hospital, Kenya. Open Journal of Pediatrics, 8 , 207-220.

https://doi.org/10.4236/ojped.2018.83023

Received: June 29, 2018

Accepted: August 17, 2018

Published: August 20, 2018

Copyright (c) 2018 by authors and Scientific Research Publishing Inc. This work is licensed under the Creative Commons Attribution International License (CC BY 4.0).

http://creativecommons.org/licenses/by/4.0/

\begin{abstract}
Introduction: Meningitis remains a common and serious problem in children worldwide. One million instances of meningitis are assessed to happen in children worldwide each year. In Africa, where outbreaks are common $70 \%$ of meningitis cases are diagnosed in children under the age of five (5) years. Though in most cases, doctors diagnose early and adequate treatment started, $5 \%$ to $10 \%$ of patients still succumb during the $24-48$ hours after onset of clinical features. In 2009, the mortality rate in Africa was four thousand deaths. Study Objective: This study describes the predictors of bacterial meningitis among children aged 0 - 5 years admitted at Kenyatta National Hospital (K.N.H.) paediatric wards. Methodology: The study adopted a descriptive cross-sectional design. It was carried out in K.N.H. paediatric wards. Data were obtained from consenting parent or guardian and healthcare workers (nurses and registrars). Study participants were selected by convenient sampling method. A total of 104 study participants were included in the study sample. In-depth interviews of key informants were conducted on 7 health workers; 5 nurses from the paediatric wards and paediatric emergency unit and 2 paediatric registrars. Ethical consideration included full disclosure to participants, confidentiality, security of health records and informed consent. Data were collected by use of researcher administered semi-structured questionnaire and desk reviews of patients' files were also used. Qualitative data from the interviews were audio-taped. Logistic regression analysis was used for data analysis. Quantitative data were cleaned, entered and analysed using Statistical Package for Social Sciences (SPSS) version 23. Results were displayed by utilization of tables, pie charts. Qualitative data were transcribed, grouped in themes and analysed manually. Study Results: The majority of the children $(55.8 \%)$ were female. The highest percentage of the children (53.8\%) was aged less than one year. The highest proportion of the parents
\end{abstract}


(39.4\%) was within the age group of 26 - 30 years. Neonatal sepsis (37.5\%), neonatal jaundice $(25.0 \%)$ and for observation $(25.0 \%)$ were the common reasons for admission to NBU. Children admitted and managed in the nursery unit were significantly 2.7 times more likely to have bacterial meningitis compared to those children never admitted to the nursery [OR $=2.75 ; 95 \%$ $\mathrm{CI}=1.08-7.00 ; \mathrm{P}=0.031]$. Streptococcus pneumonia was the main $(51.2 \%)$ causative agent of bacterial meningitis among the children. Children who were taken to hospital in delay after illness were 1.740 times more likely to exhibit meningitis than those taken to hospital immediately. Children whose parents had higher levels of income were two times less likely to exhibit meningitis than those with lower. Majority (62.5\%) resided in mid urban and slum areas. Most lived in a one (1) bed-roomed house and most houses (60.6\%) had more than five people living in it. The main co-existing illnesses among the children were pneumonia (53.8\%) and heart disease (22.9\%). Conclusions: Streptococcus pneumoniae was the common causative agent of meningitis among the study population. The enviromnetal factors such as living in overcrowded areas, inadequate exposure to health education contributed to contracting and developing meningitis. Financial contraints among caregivers posed a hindrance to the participants in seeking medical attention early. A previous upper respiratory tract infection more often led to contracting meningitis.

\section{Keywords}

Meningitis, Child, Predictors, Kenya

\section{Introduction}

Meningitis, pneumonia and sepsis in neonates and young ones ( 0 - 5 years) are among primary reasons for children demise in developing nations. These conditions have more often than not been contemplated all in all as "serious bacterial contaminations" [1]. Meningitis is hard to recognize clinically in this age assemble on the grounds that its components might be non-particular. In Bangladesh, more than a fourth of neonates with suspected sepsis; yet without clinical indications of meningitis, had cerebrospinal liquid (CSF) discoveries suggestive of meningitis. The acknowledgment of meningitis is essential given the high death rate and neuro-formative sequelae of the ailment. The last mentioned, might be higher if there should be an occurrence of a missed diagnosis or incomplete/lacking span of treatment when a new born child is observed for the less particular condition "neonatal sepsis" [2].

Bacterial meningitis occurs in about 3 children per 100,000 annually in Western countries. Population-wide studies have shown that viral meningitis is more common, at 10.9 per 100,000, and occurs more often in the summer. In Brazil, the rate of bacterial meningitis is higher, at 45.8 per 100,000 annually. Sub-Saharan Africa has been plagued by large epidemics of meningococcal meningitis for 
over a century, leading to it being labelled the "meningitis belt". Epidemics typically occur in the dry season; attack rates of 100 - 800 cases for every 100,000 are experienced in Sub-Saharan Africa, which has less efficiency in medical care [3].

In Kenya, the West Pokot region, there was an outbreak of meningitis in 2007 that recorded a case-fatality rate of $21 \%$; this was a higher record than in other African meningococcal outbreaks. Extreme remoteness of the area and the lack of clinical experience in handling meningococcal outbreaks and under detection of milder cases might be the reason for recording the high mortality [4].

The World Health Organization (WHO) guidelines list specific and general signs for meningitis. The specific signs include: convulsions, swelling fontanel for neonates and the general signs: laziness, trance like state, diminished feeding, fractiousness, anomalous cry, apnoeic scenes as signs for children aged 2 years of age and older; advising lumbar puncture (LP) if any of the above signs are present. These rules depend on confirmation from the WHO multicentre investigation of the aetiology of serious bacterial contaminations in the very young children (under five years) in low-income settings, and expert opinion [1]. The following, according to various studies are signs for predicting severity of disease among infants; feeding trouble, absence of unconstrained development, fever, unsettling, lower chest wall in drawing, tachypnea, snorting, cyanosis, shakings, protruding fontanel and moderately slow capillary refill [5].

Meningitis epidemics occur in areas where many people live together for the first time, such as army barracks, during mobilization and college campuses. The pattern of epidemic cycles in Africa is not well understood, several factors have been associated with the development of epidemics in the meningitis belt. They include: medical conditions (immunological susceptibility of the population), demographic conditions (travel and large population displacements), socioeconomic conditions (overcrowding and poor living conditions), climatic conditions (drought and dust storms), and concurrent infections (acute respiratory infections) [6].

Be that as it may, in every one of these investigations, meningitis has been gathered with bacteraemia, radiological analysed pneumonia and hypoxemia as "serious disease". Current rules for Lumbar Puncture (LP) and/or possible treatment for meningitis among neonates and young children in developing nations depend on restricted information. Besides, LP is an under-utilized examination among young children in Kenyan health facilities. This is halfway a direct result of the instability of elucidation without full biochemical and microbiological investigation of CSF, which is inadequate in many health facilities in the area [7].

\section{Methods}

\subsection{Study Design and Setting}

A descriptive cross-sectional study design was used in the study. Mixed research methods were used whereby qualitative and quantitative data were collected. The 
study was carried out within paediatric wards at Kenyatta National Hospital, Nairobi, Kenya. This is a National Referral Hospital with a bed capacity of 2000, located in Nairobi, the country's capital city. It offers both preventative and curative services for a variety of illnesses to patients from all over Kenya with an average of 600,000 outpatient visits and 89,000 inpatients annually. The paediatric department has eight inpatient wards where general medical patients, orthopaedic, oncology and surgical paediatric patients are admitted. The medical paediatric bed capacity was 256 and bed occupancy of not less than $150 \%$. Patients suffering meningitis were admitted in the four medical paediatric wards through the paediatric emergency unit.

\subsection{Study Population and Sample Size}

The study targeted children who are aged 0 - 5 years and their parents or guardians. The children who presented with meningitis and were admitted in K.N.H. paediatric wards. Data were collected from nurses and registrars who work in the paediatric emergency unit (entry point for sick children) and paediatric wards. The sample size was determined using the formula by Fisher, et al. (1998). The study was conducted from April to July 2017. A total of 104 respondents were selected in the study using purposive sampling method.

\subsection{Sampling Procedure}

1) Sampling of Study Participants

Purposeful sampling technique was used to select the study participants. All the children who were seen at paediatric emergency unit at KNH paediatric wards with clinical symptoms of meningitis and diagnosed with meningitis who met the inclusion criteria were included in the study. The children were followed up to outcome. Outcome was determined by discharge from the hospital or mortality. They were sampled as they were admitted until the sample size of participants was achieved.

2) Sampling of Interview (Nurses \& Registrars) Study Participants

Purposeful sampling technique was used to get the sample for the interviews. Interviews were conducted on nurses and doctors working in the paediatric wards and paediatric emergency unit. The researcher approached a nurse and requested him or her to participate in the interview. Preference was made to senior nurse officers (SNOs), who agreed to consent were interviewed. The nurses interviewed comprised of 1 nurse from each of the paediatric wards (3A, 3B, 3C \& 3D) and 1 from the Paediatric Emergency Unit (PEU) and 2 doctors (paediatric registrars) to make a total of 7 interview participants.

\subsection{Data Collection}

The researcher used semi-structured researcher administered questionnaire to collect data from the parent/guardian. The questionnaire was researcher designed which was pretested to determine the content, construct and criterion va- 
lidity. The study instrument was pretested in Mbagathi District hospital in Nairobi. Reliability of the study tools was done to pretest the tool by using $10 \%$ (11 respondents) of the study sample size.

Desk review procedure was used to obtain data by the researcher. A key informant interview guide was used to collect qualitative data from the nurses and doctors who participated in giving care to the study participants.

\subsection{Data Analysis}

Data collected were entered into Microsoft Excel spreadsheet and analysis done using statistical package for social sciences (SPSS) version 23. Logistic regression analysis was also used. Pearson's chi-square test was used to establish the association between the dependent variable and independent variables in order to determine which ones had significant association. Transcribed qualitative data were categorized into themes and analyzed manually.

\subsection{Ethical Consideration}

Study approval was sought from the Kenyatta National Hospital/University of Nairobi Ethics and Research committee (KNH/UON-ERC). Written informed consent was sought from all study participants after they were given participant information, before they were interviewed. Participation was purely on voluntary basis and participants could withdraw at any point of the study. Privacy and confidentiality was maintained while handling participants' information.

\section{Results}

\section{1) Child's Demographic Characteristics and Bacterial Meningitis}

Table 1 shows the relationship of children's demographic characteristics and bacterial meningitis. Children admitted and managed in the nursery unit after delivery were significantly 2.7 times more likely to have bacterial meningitis compared to those children never admitted in nursery after delivery $[\mathrm{OR}=2.75$; $95 \% \mathrm{CI}=1.08-7.00 ; \mathrm{P}=0.031]$.

Even though the odds of bacterial meningitis among children who were not fully immunized as per age (63.6\%) than fully immunized (36.6\%) was three times, it was not statistically significant (Table 2).

\section{2) Parents' Demographic Characteristics and Bacterial Meningitis}

Analysis of association between parents' demographic characteristics and bacterial meningitis among the children is shown in Table 3 .

\section{3) Socio-Economic Characteristics of the Parents}

Table 4 demonstrates the distribution of parents' socio-economic characteristics. More than half of the parents 56 (53.8\%) had formal occupation. The highest percentage of the parents 41 (39.4\%) had Kshs. 30,000 to Kshs. 40,000 Kenyan shillings per month as gross income followed by 10,000 - 20,000 Kenyan shillings 37 (35.6\%).

4) Common Documented Causative Agents of Bacterial Meningitis 
Table 1. Association between child's demographic characteristics and bacterial meningitis.

\begin{tabular}{|c|c|c|c|c|c|c|c|c|}
\hline \multirow{2}{*}{ Variables } & \multicolumn{2}{|c|}{$\begin{array}{l}\text { Bacterial } \\
\text { infection }\end{array}$} & \multicolumn{2}{|c|}{$\begin{array}{l}\text { Non bacterial } \\
\text { infection }\end{array}$} & \multirow{2}{*}{ OR } & \multicolumn{2}{|c|}{$95 \%$ CI } & \multirow{2}{*}{$\begin{array}{l}\chi^{2} \text { test } \\
\text { P value }\end{array}$} \\
\hline & $\mathrm{n}$ & $\%$ & $\mathrm{n}$ & $\%$ & & Lower & Upper & \\
\hline \multicolumn{9}{|c|}{ Gender } \\
\hline Male & 19 & $41.3 \%$ & 27 & $58.7 \%$ & 1.15 & 0.52 & 2.54 & 0.727 \\
\hline Female & 22 & $37.9 \%$ & 36 & $62.1 \%$ & Ref & & & \\
\hline \multicolumn{9}{|c|}{ Age } \\
\hline$<1$ year & 23 & $41.1 \%$ & 33 & $58.9 \%$ & 1.26 & 0.49 & 3.21 & 0.636 \\
\hline 1 to 2 years & 8 & $40.0 \%$ & 12 & $60.0 \%$ & 1.20 & 0.37 & 3.91 & 0.762 \\
\hline 3 to 5 years & 10 & $35.7 \%$ & 18 & $64.3 \%$ & Ref & & & \\
\hline \multicolumn{9}{|c|}{ Mode of deliver } \\
\hline Spontaneous Vaginal delivery & 31 & $37.3 \%$ & 52 & $62.7 \%$ & Ref & & & \\
\hline Caesarean section & 10 & $47.6 \%$ & 11 & $52.4 \%$ & 1.53 & 0.58 & 4.00 & 0.391 \\
\hline \multicolumn{9}{|c|}{ Was the baby admitted to new born unit } \\
\hline Yes & 14 & $58.3 \%$ & 10 & $41.7 \%$ & 2.75 & 1.08 & 7.00 & 0.031 \\
\hline No & 27 & $33.8 \%$ & 53 & $66.3 \%$ & Ref & & & \\
\hline \multicolumn{9}{|c|}{ Immunization history } \\
\hline Fully immunized as per age & 34 & $36.6 \%$ & 59 & $63.4 \%$ & Ref & & & \\
\hline Not fully immunized as per age & 7 & $63.6 \%$ & 4 & $36.4 \%$ & 3.04 & 0.83 & 11.13 & 0.094 \\
\hline
\end{tabular}

Table 2. Child's demographic characteristics and bacterial meningitis.

\begin{tabular}{|c|c|c|c|c|c|c|c|c|}
\hline \multirow[t]{2}{*}{ Variables } & \multicolumn{2}{|c|}{$\begin{array}{l}\text { Bacterial } \\
\text { infection }\end{array}$} & \multicolumn{2}{|c|}{$\begin{array}{c}\text { Non bacterial } \\
\text { infection }\end{array}$} & \multirow[t]{2}{*}{ OR } & \multicolumn{2}{|c|}{$95 \% \mathrm{CI}$} & \multirow{2}{*}{$\begin{array}{l}\chi^{2} \text { test } \\
\text { P value }\end{array}$} \\
\hline & $\mathbf{n}$ & $\%$ & $\mathbf{n}$ & $\%$ & & Lower & Upper & \\
\hline \multicolumn{9}{|c|}{ Gender } \\
\hline Male & 19 & $41.3 \%$ & 27 & $58.7 \%$ & 1.15 & 0.52 & 2.54 & 0.727 \\
\hline Female & 22 & $37.9 \%$ & 36 & $62.1 \%$ & Ref & & & \\
\hline \multicolumn{9}{|c|}{ Age } \\
\hline$<1$ year & 23 & $41.1 \%$ & 33 & $58.9 \%$ & 1.26 & 0.49 & 3.21 & 0.636 \\
\hline 1 to 2 years & 8 & $40.0 \%$ & 12 & $60.0 \%$ & 1.20 & 0.37 & 3.91 & 0.762 \\
\hline 3 to 5 years & 10 & $35.7 \%$ & 18 & $64.3 \%$ & Ref & & & \\
\hline \multicolumn{9}{|c|}{ Mode of delivery } \\
\hline Spontaneous Vaginal delivery & 31 & $37.3 \%$ & 52 & $62.7 \%$ & Ref & & & \\
\hline Caesarean section & 10 & $47.6 \%$ & 11 & $52.4 \%$ & 1.53 & 0.58 & 4.00 & 0.391 \\
\hline \multicolumn{9}{|c|}{ Admission to new born unit } \\
\hline Yes & 14 & $58.3 \%$ & 10 & $41.7 \%$ & 2.75 & 1.08 & 7.00 & 0.031 \\
\hline No & 27 & $33.8 \%$ & 53 & $66.3 \%$ & Ref & & & \\
\hline \multicolumn{9}{|c|}{ Immunization history } \\
\hline Fully immunized as per age & 34 & $36.6 \%$ & 59 & $63.4 \%$ & Ref & & & \\
\hline Not fully immunized as per age & 7 & $63.6 \%$ & 4 & $36.4 \%$ & 3.04 & 0.83 & 11.13 & 0.094 \\
\hline
\end{tabular}

OR $=$ Odds Ratio, $\mathrm{CI}=$ Confidence Interval, $\chi^{2}=$ Chi-Square, Ref $=$ Reference . 
Table 3. Parents' demographic characteristics and bacterial meningitis.

\begin{tabular}{|c|c|c|c|c|c|c|c|c|}
\hline \multirow[t]{2}{*}{ Variables } & \multicolumn{2}{|c|}{$\begin{array}{l}\text { Bacterial } \\
\text { infection }\end{array}$} & \multicolumn{2}{|c|}{$\begin{array}{l}\text { Non bacterial } \\
\text { infection }\end{array}$} & \multirow[t]{2}{*}{ OR } & \multicolumn{2}{|c|}{$95 \% \mathrm{CI}$} & \multirow{2}{*}{$\begin{array}{l}\chi^{2} \text { test } \\
\text { P value }\end{array}$} \\
\hline & $\mathrm{n}$ & $\%$ & $\mathrm{n}$ & $\%$ & & Lower & Upper & \\
\hline \multicolumn{9}{|c|}{ Parent's age in years } \\
\hline Below 26 & 12 & $34.3 \%$ & 23 & $65.7 \%$ & Ref & & & \\
\hline $26-30$ & 16 & $39.0 \%$ & 25 & $61.0 \%$ & 1.23 & 0.48 & 3.14 & 0.670 \\
\hline $30-49$ & 13 & $46.4 \%$ & 15 & $53.6 \%$ & 1.66 & 0.60 & 4.60 & 0.329 \\
\hline \multicolumn{9}{|c|}{ Parent's level of education } \\
\hline Have no formal education & 3 & $50.0 \%$ & 3 & $50.0 \%$ & 1.83 & 0.32 & 10.53 & 0.497 \\
\hline Primary level & 10 & $47.6 \%$ & 11 & $52.4 \%$ & 1.67 & 0.55 & 5.05 & 0.366 \\
\hline Secondary level & 16 & $37.2 \%$ & 27 & $62.8 \%$ & 1.09 & 0.43 & 2.77 & 0.862 \\
\hline College/University level & 12 & $35.3 \%$ & 22 & $64.7 \%$ & Ref & & & \\
\hline \multicolumn{9}{|c|}{ Parent's religion } \\
\hline Protestant & 19 & $39.6 \%$ & 29 & $60.4 \%$ & 1.31 & 0.11 & 15.48 & 0.830 \\
\hline Catholic & 21 & $39.6 \%$ & 32 & $60.4 \%$ & 1.31 & 0.11 & 15.41 & 0.829 \\
\hline Muslim & 1 & $33.3 \%$ & 2 & $66.7 \%$ & Ref & & & \\
\hline \multicolumn{9}{|c|}{ Parent's marital status } \\
\hline Single & 4 & $36.4 \%$ & 7 & $63.6 \%$ & 0.86 & 0.10 & 7.51 & 0.889 \\
\hline Married & 35 & $39.8 \%$ & 53 & $60.2 \%$ & 0.99 & 0.16 & 6.23 & 0.992 \\
\hline Separated/widowed & 2 & $40.0 \%$ & 3 & $60.0 \%$ & Ref & & & \\
\hline
\end{tabular}

$\mathrm{OR}=$ Odds Ratio, $\mathrm{CI}=$ Confidence Interval, $\chi^{2}=$ Chi-Square, Ref $=$ Reference.

Table 4. Socio-economic factors of the parents.

\begin{tabular}{|c|c|c|c|}
\hline Variable & Category & $\mathrm{N}=104$ & $\%$ \\
\hline \multirow{4}{*}{ Occupation } & Self-employed & 19 & 18.3 \\
\hline & In formal employment & 56 & 53.8 \\
\hline & Not-employed & 29 & 27.9 \\
\hline & $<10,000$ & 19 & 18.3 \\
\hline \multirow{4}{*}{$\begin{array}{l}\text { Gross income per month } \\
\text { (Kshs) }\end{array}$} & $10,000-20,000$ & 37 & 35.6 \\
\hline & $30,000-40,000$ & 41 & 39.4 \\
\hline & $>40,000$ & 7 & 6.7 \\
\hline & Mid-level urban setting & 48 & 46.1 \\
\hline \multirow[t]{3}{*}{ Residence } & Urban slum area & 32 & 30.8 \\
\hline & Rural area & 24 & 23.1 \\
\hline & Single room & 10 & 9.6 \\
\hline \multirow[t]{3}{*}{ Structure of the house } & One bed-roomed plus sitting room & 29 & 27.9 \\
\hline & More than 1 bed-roomed plus sitting room & 65 & 62.5 \\
\hline & Less than three & 5 & 4.8 \\
\hline \multirow{3}{*}{$\begin{array}{c}\text { Number of people living in } \\
\text { the house }\end{array}$} & 3 to 5 & 35 & 33.7 \\
\hline & More than five & 63 & 60.6 \\
\hline & $<$ a kilometer & 12 & 11.5 \\
\hline \multirow{2}{*}{$\begin{array}{c}\text { Distance to the nearest } \\
\text { health facility }\end{array}$} & 1 - 5 kilometers & 6 & 5.8 \\
\hline & More than 5 kilometers & 86 & 82.7 \\
\hline
\end{tabular}


Streptococcus pneumonia was the main (51.2\%) causative agent of bacterial meningitis among the children (Figure 1).

5) Pre-Existing/Co-Existing Conditions and Bacterial Meningitis

Table 5 below shows association between pre-existing/co-existing conditions and bacterial meningitis among children. The proportion of bacterial meningitis was more among children with stiff neck, among those who refused to feed and those with abnormal cry.

6) Types of Co-Existing Childhood Illnesses

As indicated in Figure 2, the main co-existing illnesses among the children were heart disease (22.9\%) and pulmonary TB (20.0\%). N.B: The percentages are taken to a total responses and not respondents as some respondents had more than one option to respond to.

\section{Discussion}

\subsection{Child Demographic Characteristics}

Majority (54\%) of the children were aged one (1) year old \pm 1 month with $41 \%$ of them having positive lumbar puncture results for bacterial meningitis.

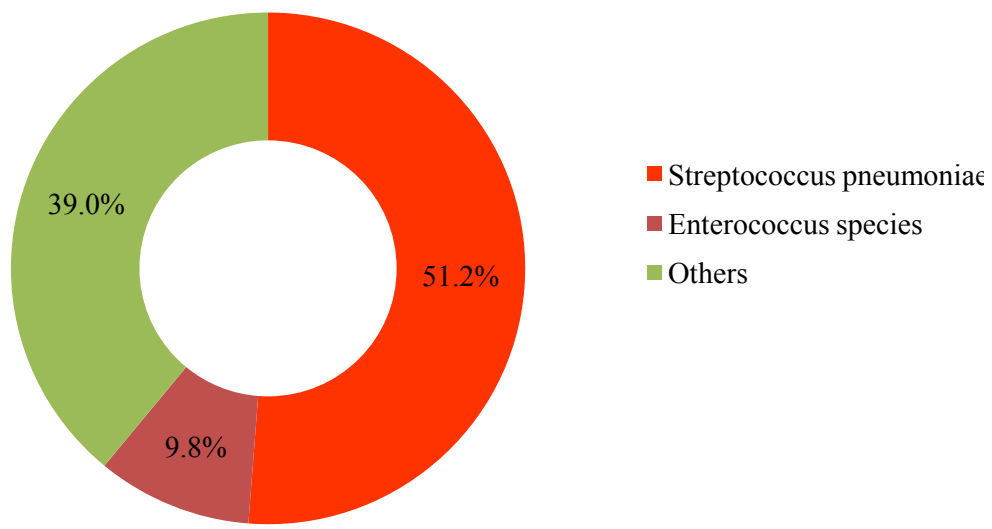

Figure 1. Common documented causative agents of bacterial meningitis.

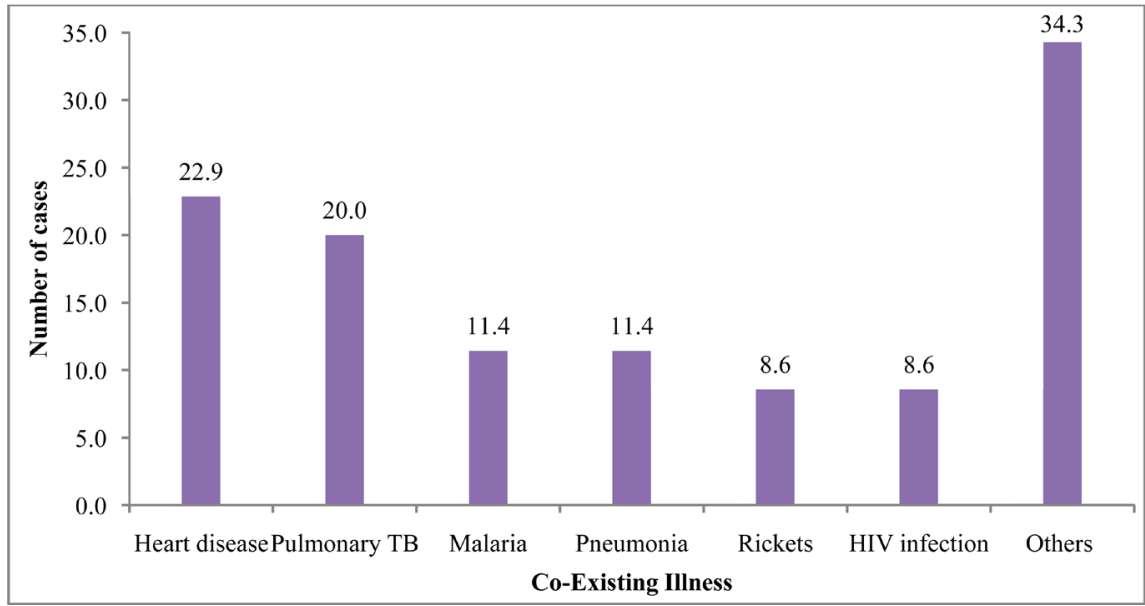

Figure 2. Types of co-existing childhood illnesses. 
Table 5. Pre-existing/co-existing conditions and bacterial meningitis.

\begin{tabular}{|c|c|c|c|c|c|c|c|c|}
\hline \multirow[t]{2}{*}{ Variables } & \multicolumn{2}{|c|}{$\begin{array}{l}\text { Bacterial } \\
\text { infection }\end{array}$} & \multicolumn{2}{|c|}{$\begin{array}{l}\text { Non bacterial } \\
\text { infection }\end{array}$} & \multirow[t]{2}{*}{ OR } & \multicolumn{2}{|c|}{$95 \% \mathrm{CI}$} & \multirow{2}{*}{$\begin{array}{l}\chi^{2} \text { test } \\
\text { P value }\end{array}$} \\
\hline & $\mathbf{n}$ & $\%$ & $\mathrm{n}$ & $\%$ & & Lower & Upper & \\
\hline \multicolumn{9}{|c|}{ How long after birth did your child get ill } \\
\hline 0 - 7 days & 6 & $42.9 \%$ & 8 & $57.1 \%$ & 1.42 & 0.37 & 5.37 & 0.608 \\
\hline 8 - 28 days & 4 & $44.4 \%$ & 5 & $55.6 \%$ & 1.51 & 0.32 & 7.07 & 0.600 \\
\hline$>28$ days & 22 & $40.0 \%$ & 33 & $60.0 \%$ & 1.26 & 0.48 & 3.33 & 0.642 \\
\hline$>1$ year & 9 & $34.6 \%$ & 17 & $65.4 \%$ & Ref & & & \\
\hline \multicolumn{9}{|c|}{ Child suffered from Otitis } \\
\hline Yes & 4 & $36.4 \%$ & 7 & $63.6 \%$ & 0.87 & 0.24 & 3.16 & 0.826 \\
\hline No & 37 & $39.8 \%$ & 56 & $60.2 \%$ & Ref & & & \\
\hline \multicolumn{9}{|c|}{ Child suffered from Sinusitis } \\
\hline Yes & 5 & $41.7 \%$ & 7 & $58.3 \%$ & 1.11 & 0.33 & 3.77 & 0.866 \\
\hline No & 36 & $39.1 \%$ & 56 & $60.9 \%$ & Ref & & & \\
\hline \multicolumn{9}{|c|}{ Child suffered from Pneumonia } \\
\hline Yes & 20 & $35.7 \%$ & 36 & $64.3 \%$ & 0.71 & 0.32 & 1.57 & 0.403 \\
\hline No & 21 & $43.8 \%$ & 27 & $56.3 \%$ & Ref & & & \\
\hline \multicolumn{9}{|c|}{ Child had any co-existing childhood illness } \\
\hline Yes & 17 & $39.5 \%$ & 26 & $60.5 \%$ & 1.01 & 0.45 & 2.24 & 0.984 \\
\hline No & 24 & $39.3 \%$ & 37 & $60.7 \%$ & Ref & & & \\
\hline \multicolumn{9}{|c|}{ Child is on treatment for the co-existing illness } \\
\hline Yes & 17 & $40.5 \%$ & 25 & $59.5 \%$ & 1.08 & 0.48 & 2.40 & 0.856 \\
\hline No & 24 & $38.7 \%$ & 38 & $61.3 \%$ & Ref & & & \\
\hline \multicolumn{9}{|c|}{ Refusal to feed } \\
\hline Yes & 35 & $41.2 \%$ & 50 & $58.8 \%$ & 1.52 & 0.53 & 4.38 & 0.439 \\
\hline No & 6 & $31.6 \%$ & 13 & $68.4 \%$ & Ref & & & \\
\hline \multicolumn{9}{|c|}{ Abnormal cry } \\
\hline Yes & 27 & $45.8 \%$ & 32 & $54.2 \%$ & 1.87 & 0.83 & 4.21 & 0.130 \\
\hline No & 14 & $31.1 \%$ & 31 & $68.9 \%$ & Ref & & & \\
\hline \multicolumn{9}{|c|}{ Convulsions } \\
\hline Yes & 38 & $38.8 \%$ & 60 & $61.2 \%$ & 0.63 & 0.12 & 3.30 & 0.585 \\
\hline No & 3 & $50.0 \%$ & 3 & $50.0 \%$ & Ref & & & \\
\hline \multicolumn{9}{|c|}{ Bulging Fontanel } \\
\hline Yes & 9 & $34.6 \%$ & 17 & $65.4 \%$ & 0.76 & 0.30 & 1.92 & 0.562 \\
\hline No & 32 & $41.0 \%$ & 46 & $59.0 \%$ & Ref & & & \\
\hline \multicolumn{9}{|c|}{ Irritability } \\
\hline Yes & 29 & $39.2 \%$ & 45 & $60.8 \%$ & 0.97 & 0.41 & 2.30 & 0.939 \\
\hline No & 12 & $40.0 \%$ & 18 & $60.0 \%$ & Ref & & & \\
\hline \multicolumn{9}{|c|}{ Stiff neck } \\
\hline Yes & 18 & $43.9 \%$ & 23 & $56.1 \%$ & 1.36 & 0.61 & 3.04 & 0.451 \\
\hline No & 23 & $36.5 \%$ & 40 & $63.5 \%$ & Ref & & & \\
\hline
\end{tabular}

$\mathrm{OR}=$ Odds Ratio, $\mathrm{CI}=$ Confidence Interval, $\chi^{2}=$ Chi-Square, Ref $=$ Reference. 
Children in this age group are more susceptible to infection due to their underdeveloped immune system and therefore disease is likely to occur when exposed to bacteria or pathogens. A Kenyan study reported that $3 \%-6 \%$ of all children admissions $<59$ days old were due to meningitis, with case fatality ratios of $26 \%$ in the first week of life and $18 \%$ between 7 and 59 days of age [5].

The current study findings reported female children (56\%) were more at risk of being affected with clinical symptoms of meningitis compared to their male counterparts (44\%). About $38 \%$ of the children diagnosed with bacterial meningitis were female and this contradicts a study in Australia that reported that males contract meningitis more regularly than their female counterparts [8].

The $37 \%$ of children who had bacterial meningitis were delivered via spontaneous vaginal delivery. However, no difference was observed regarding mode of delivery and likelihood of contracting meningitis. Normal flora present in the birth canal can cause life threatening CNS infections in the neonates either after intra-uterine infection or through vertical transmission during birth. The normal vagina has organisms such as group B streptococci, alpha streptococci, $E$. coli which multiply in number during pregnancy [9]; this may predispose a neonate to infection such as meningitis caused by streptococcus species either in the neonatal period or infancy period.

Children admitted and managed in the nursery unit after delivery were significantly three times more likely to have bacterial meningitis compared to those children never admitted in nursery after delivery. Admission to the new born unit has a significant risk in the eventual health of the child. The neonate can acquire iatrogenic infections and/or sepsis which can cascade to developing life threatening illness such as meningitis.

Even though the odds of contracting bacterial meningitis were three times more (64\%) among children who were not fully immunized as per age than fully immunized (37\%), this was not statistically significant. This is in agreement with a study done in Malawi on acute bacterial meningitis (ABM) that reported that the decline in childhood cases of $S$. pneumonia ABM in children aged 3 months to $<5$ years preceding the introduction of PCV13 has not been observed in other sub-Saharan African facility-based studies [10].

\subsection{Parental Demographic Characteristics}

The mean age of the parents whose children were admitted with bacterial meningitis was 28 years of age \pm 2 . This is a relatively young age. The young mothers/parents face challenges as regards child care as they are still continuing in learning skills and techniques of parenthood. This could have contributed to their children contracting meningitis.

Economic empowerment of guardians/parents is a key pillar towards attainment of optimum health. Lack of economic independence and poverty among the population that was unemployed (28\%), may have contributed to delaying in seeking healthcare upon realizing that the child was unwell. Financial detriment 
builds the danger of meningitis. US studies have reliably found that individuals of African-American origin, individuals of low financial status, low maternal education and other antagonistic social attributes were related with expanded danger of infection with meningitis [11].

Majority of the parents (54\%) had formal employment with a gross family income of between Kshs. 10,000 to Kshs. 40,000 per month. Only 6\% of the parents had a gross family income of Kshs. 40,000 and above. This means that the parent(s) were economically dependent on some economic network system. Children whose parents had higher levels of income were twice less likely to exhibit meningitis than those with lower income levels. This is in accordance with a study done in Brazil that reported the frequency of the illness was around two times higher in low financial zones than in more prosperous zones [12].

\subsection{Common Causative Agents}

Streptococcus pneumonia was the common causative agent at $51 \%$ of bacterial meningitis among the study age group; this is a well-known fact. This also is in agreement with a study done in Malawi that reported Streptococcus pneumoniae is the predominant bacterial pathogen causing $65 \%$ of infections in the 2 to 15-year age group [13]. Exposure to streptococcus species from the birth canal may be the start of a cascade of events that eventually lead to contracting meningitis among children aged 0 - 5 years. Recurrent upper respiratory tract infections can also be attributed to infection with $S$. pneumonia. Another study reported that $S$. pneumonia is the real reason for childhood bacterial meningitis in many nations especially in those where Hib illness has been killed by immunization [8].

The lumbar puncture results showed $39 \%$ of the tests done were positive for bacterial meningitis. CSF glucose had a mean of $4.4 \mathrm{mmol} / \mathrm{L}$ which was within normal levels with reference ranges of $2.5-7.0 \mathrm{mmol} / \mathrm{L}$.

CSF protein concentration is one of the most sensitive indicators of pathology within the central nervous system. CSF protein had an average mean of 650 $\mathrm{mmol} / \mathrm{L}$ which is elevated for the reference range of $150-450 \mathrm{mmol} / \mathrm{L}$; this is in accordance with documented data that the CSF protein is significantly higher in bacterial meningitis caused by all pathogens [4]. CSF appearance of the samples was taken; $49 \%$ were clear and $36 \%$ were cloudy; both appearances of which are positive indicators for bacterial meningitis caused by all pathogens.

\subsection{Environmental Factors}

Forty-six percent (46\%) of the study population resided in urban areas. The environment of children who live in urban areas and the hazards they are exposed to in urban areas is not the same as that of children who reside in rural areas. In urban areas, children are exposed to fumes, smoke, poor hygiene, poor sanitation, changes in weather conditions. It can be hypothesized that; high temperatures coupled with environmental hazards may favor the conversion of benign 
meningitis that is bacteria in the nose and throat to pathogenic bacteria by damaging the mucosa and lowering immune defense and resulting in completion of the disease process and diagnosis of meningitis [14].

Increasing number of people living in the household was associated with an increased likelihood of contracting meningitis; $61 \%$ of the participants lived more than 5 people in a bedroomed house.

In the East Africa region, Kenya for example, the cost of treating a case of meningitis often equates to two times a rural or slum family's annual income [5]. The situation predisposes people to live in overcrowded areas, slums and areas with poor sanitation putting them and their children at great risk of contracting meningitis and other illnesses.

\subsection{Co-Morbidities}

Meningitis may occur after either an acute or subacute/chronic infection. Forty-one percent (41\%) of the respondents had co-existing childhood illness. 54\% of the study participants suffered from pneumonia. Therefore, it can be hypothesized that the odds for contracting meningitis after ailment from pneumonia was high among the study population.

\section{Conclusions}

Bacterial meningitis was most common among female infants and the prevalence was higher if the infant was hospitalised during the first twenty-eight days of life either in the new born unit or in the paediatric ward. Streptococcus pneumoniae was the common causative agent of meningitis among the study population and that vaccination with PCV has incredibly helped lower the incidence. A previous upper respiratory tract infection with pneumonia more often led to contracting or presenting with meningitis among the children studied.

The researcher proposes the introduction of meningococcal vaccine to the division for vaccine and immunization (DVI) schedule along with the routine vaccination of PCV to reduce the likelihood of contracting meningitis.

\section{Acknowledgements}

The authors wish to give special thanks to the Kenyatta National administration for their cooperation and for granting the approval to conduct the study.

\section{Competing Interest}

The authors declare that they have no competing interests.

\section{Funding}

This research was not funded.

\section{References}

[1] World Health Organization (2012) Detecting Meningococcal Meningitis Epidemics 
in Highly-Endemic African Countries. Weekly Epidemiological Record, 78, 294-296.

[2] Zahn, C.A., Morrell, M.J., Collins, S.D., Labiner, D.M. and Yerby, M.S. (2008) Management Issues for Women with Epilepsy: A Review of the Literature. Neurology, 51, 949-956. https://doi.org/10.1212/WNL.51.4.949

[3] Sáez-Llorens, X. and McCracken Jr., G.H. (2009) Bacterial Meningitis in Children. The Lancet, 361, 2139-2148. https://doi.org/10.1016/S0140-6736(03)13693-8

[4] Mutonga, D.M., Pimentel, G., Muindi, J., Nzioka, C., Mutiso, J., et al. (2008) Epidemiology and Risk Factors for Serogroup X Meningococcal Meningitis during an Outbreak in Western Kenya. The American Journal of Tropical Medicine and Hygiene, 80, 619-624.

[5] Mwaniki, M.K., Talbert, A.W., Njuguna, P., English, M., Were, E., Lowe, B.S. and Berkley, J.A. (2011) Clinical Indicators of Bacterial Meningitis among Neonates and Young Infants in Rural Kenya. BMC Infectious Diseases, 11, 301. https://doi.org/10.1186/1471-2334-11-301

[6] Bishai, D.M., Champion, C., Steele, M.E. and Thompson, L. (2011) Product Development Partnerships Hit Their Stride: Lessons from Developing a Meningitis Vaccine for Africa. Health Affairs, 30, 1058-1064.

https://doi.org/10.1377/hlthaff.2011.0295

[7] Berkley, J.A., Mwangi, I., Ngetsa, C.J., Mwarumba, S., Lowe, B.S. and Marsh, K. (2001) Diagnosis of Acute Bacterial Meningitis in Children at a District Hospital in Sub-Saharan Africa. The Lancet, 357, 1753-1757.

[8] Robinson, P., Taylor, K. and Nolan, T. (2010) Risk-Factors for Meningococcal Disease in Victoria, Australia, in 1997. Epidemiology \& Infection, 127, 261-268.

[9] Brook, I. (2007) Microbiology of Acute Sinusitis of Odontogenic Origin Presenting with Periorbital Cellulitis in Children. Annals of Otology, Rhinology \& Laryngology, 116, 386-388. https://doi.org/10.1177/000348940711600512

[10] Feikin, D.R., Jagero, G., Aura, B., et al. (2010) High Rate of Pneumococcal Bacteremia in a Prospective Cohort of Older Children and Adults in an Area of High HIV Prevalence in Rural Western Kenya. BMC Infectious Diseases, 10, 186. https://doi.org/10.1186/1471-2334-10-186

[11] Grimwood, K., Andersonb, P., Andersonb, V., Tanc, L. and Nolan, T. (2000) Twelve Year Outcomes Following Bacterial Meningitis: Further Evidence for Persisting Effects. Archives of Disease in Childhood, 83, 111-116. https://doi.org/10.1136/adc.83.2.111

[12] Kriz, P., Bobak, M. and Kriz, B. (2000) Parental Smoking, Socioeconomic Factors, and Risk of Invasive Meningococcal Disease in Children: A Population Based Case-Control Study. Archives of Disease in Childhood, 83, 117-121. https://doi.org/10.1136/adc.83.2.117

[13] Peltola, H. (2001) Burden of Meningitis and Other Severe Bacterial Infections of Children in Africa: Implications for Prevention. Clinical Infectious Diseases, 32, 64-75. https://doi.org/10.1086/317534

[14] Letson, G.W., Gellin, B.G., Bulkow, L.R., Parks, D.J. and Ward, J.I. (2012) Severity and Frequency of Sequelae of Bacterial Meningitis in Alaska Native Infants. Correlation with a Scoring System for Severity of Sequelae. The American Journal of Diseases of Children, 146, 560-566.

https://doi.org/10.1001/archpedi.1992.02160170040013 


\section{Abbreviations}

DVI-Division for vaccine and immunization

PCV-Pneumococcal vaccine

$\mathrm{KNH}-$ Kenyatta national hospital 